\title{
The effects of changes in water and nitrogen availability on alien plant invasion into a stand of a native grassland species
}

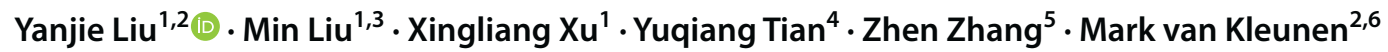

\begin{abstract}
Plant invasions are a major component of global change, but they may be affected by other global change components. Here we used a mesocosm-pot experiment to test whether high water availability, nitrogen $(\mathrm{N})$ enrichment and their interaction promote performance of three invasive alien plants (Lepidium virginicum, Lolium perenne and Medicago sativa) when competing with a native Chinese grassland species (Agropyron cristatum). Single plants of the three invasive and the one native species were grown in the center of pots with a matrix of the native A. cristatum under low, intermediate or high water availability and low or high $\mathrm{N}$ availability. The invasive species L. virginicum and M. sativa grew larger, and produced a higher biomass relative to competitors than the native species A. cristatum did. Increasing water availability promoted biomass production of all species, but water availability did not change the biomass of the central plants relative to that of the competitors. Nitrogen addition also increased biomass production of all species, and it increased the biomass of the central plants more so than that of the competitors. The positive effect of $\mathrm{N}$ addition on the biomass of the central plants relative to that of the competitors increased with increasing water availability. However, compared to central plants of the native species, the positive effect of $\mathrm{N}$ addition on the relative biomass of $L$. virginicum decreased when water availability increased. These interactions indicate that future changes in water availability and $\mathrm{N}$ enrichment may affect the invasion success of different alien species differently.
\end{abstract}

Keywords Exotic $\cdot$ Global change $\cdot$ Non-native $\cdot$ Plant invasion $\cdot$ Plant-plant interaction

Communicated by Wayne Dawson.

Yanjie Liu and Min Liu contributed equally to this work.

Yanjie Liu

yanjie.liu@uni-konstanz.de

$\triangle$ Xingliang Xu xuxingl@hotmail.com

1 Key Laboratory of Ecosystem Network Observation and Modeling, Institute of Geographic Sciences and Natural Resources Research, Chinese Academy of Sciences, 11A Datun Road, Chaoyang District, Beijing 100101, China

2 Ecology, Department of Biology, University of Konstanz, Universitätsstraße 10, 78457 Konstanz, Germany

3 University of Chinese Academy of Sciences, Beijing 100049, China

\section{Introduction}

Owing to the increasing influence of human activities, at least $3.9 \%$ of species in the global vascular flora have established naturalized populations in regions where they did not naturally occur (van Kleunen et al. 2015a; Pyšek et al. 2017). It is very likely that the number of these naturalized

$4 \quad$ State Key Laboratory of Earth Surface Processes and Resource Ecology, Center for Human-Environment System Sustainability (CHESS), Beijing Normal University, Haidian District, Beijing 100875, China

5 School of Resources and Environment, Anhui Agricultural University, NO. 130 Changjiang West Road, Hefei 230036, China

6 Zhejiang Provincial Key Laboratory of Plant Evolutionary Ecology and Conservation, Taizhou University, Taizhou 318000, China 
plant species will continue to increase in the future (Seebens et al. 2015, 2017). Some naturalized plant species can successfully spread and occupy large areas in high abundances in the introduced ranges (i.e., become invasive sensu Richardson et al. 2000). The human-caused introduction, naturalization and subsequent spread of alien plant species into new regions has become a major component of global environmental change, and one of the defining characteristics of the Anthropocene (Lewis and Maslin 2015). The invasive plant species frequently have higher values than native plants for traits reflecting physiology, size and fitness (van Kleunen et al. 2010). Consequently, it is generally thought that invasive alien plant species outperform and displace native plants, and thus threaten native diversity, disrupt ecosystem functions and services (Vitousek et al. 1996; Vilà et al. 2011). Therefore, understanding the competition between invasive alien and native plants and assessing the potential invasion risk of naturalized alien plants are hot topics in ecology.

As a major component of global environmental change, plant invasions are also likely to interact with other global change components (Bradley et al. 2010a). For example, a recent meta-analysis suggests that different components of global environmental change can promote the growth of alien plants mainly via an increase in growth rate and size (Jia et al. 2016). Furthermore, our recent meta-analysis comparing the growth performance responses to global environmental changes between 74 invasive alien and 117 native plants has shown that invasive alien species benefitted significantly more from increased atmospheric $\mathrm{CO}_{2}$ levels and temperatures than native species, and also tended to benefit more from nutrient addition (Liu et al. 2017). However, both meta-analyses point out that most studies only tested how plant invasions interact with individual components of global environmental change, whereas the interacting effects of multiple global change components on invasions remain unclear (Jia et al. 2016; Liu et al. 2017).

Global environmental change has a strong effect on plant growth and community structure in grasslands (Shaw et al. 2002; Zavaleta et al. 2003; Keller et al. 2014). Temperate grasslands are widely distributed across the Eurasian continent and known as "the Eurasian steppes" (Bredenkamp et al. 2002). Such grasslands constitute the main habitat in northern China. In this region, low water availability is the major factor limiting grassland productivity. With global climate change, precipitation is likely to increase in some regions and decrease in other regions (Naz et al. 2016). Moreover, there are some uncertainties about future precipitation levels, and it is likely that the frequencies of extremely dry and wet years will increase (IPCC 2013). The changes in water availability could affect competition between alien and native plants (Liu et al. 2017; Pearson et al. 2017). For example, wet condition may favor (Bradley et al. 2010b), and drought condition may inhibit invasive plant species (Liu et al. 2017) more than native plant species. However, it has not yet been explored how water availability changes interact with alien plant invasion in temperate grasslands.

As a major component of global environmental change, nitrogen $(\mathrm{N})$ deposition is likely to further increase soil $\mathrm{N}$ availability in many terrestrial ecosystems worldwide (Holland et al. 2005; Phoenix et al. 2006; Liu et al. 2013). It might affect the productivity of temperate grasslands by changing plant-plant interactions, because $\mathrm{N}$ is another important factor limiting the productivity of grasslands (LeBauer and Treseder 2008). Invasive plant species may outperform native plant species under conditions of low nutrient availability (Funk and Vitousek 2007). However, successful alien plant species are often associated with a particular suite of traits that enable them to respond more positively to increased N availability. (Dawson et al. 2012; Keser et al. 2014, 2015; Liu and van Kleunen 2017). Consequently, it is frequently suggested that invasive plants are more successful and outperform the native plants in areas with high N deposition (Scherer-Lorenzen et al. 2000, 2007; González et al. 2010). Therefore, it is important to test how $\mathrm{N}$ deposition interacts with alien plant invasion in the temperate grasslands of China.

Various components of global environmental change may occur simultaneously, and these changes may additively or interactively impact plant performance (Dukes et al. 2005; Bloor et al. 2010). In temperate grasslands, the effect of soil $\mathrm{N}$ on grassland productivity and composition usually depends on soil-water availability (Harpole et al. 2007; Bai et al. 2008; Lu and Han 2010; Li et al. 2011). As water can enhance $\mathrm{N}$ delivery to the root surface, the effects of $\mathrm{N}$ addition on grassland productivity might become stronger with increasing water availability (Bai et al. 2008; Lu and Han 2010). As it remains poorly understood how these two environmental factors interact in their effects on alien plant invasion (Jia et al. 2016; Liu et al. 2017), we performed a mesocosm-pot experiment to test whether $\mathrm{N}$ enrichment could interact with water availability to promote further invasion of invasive alien plant species into a stand of the native grassland species Agropyron cristatum. We grew single plants of three invasive alien plant species (Lepidium virginicum, Lolium perenne and Medicago sativa) and one native species (A. cristatum) in a matrix of the native species under three water conditions (low, intermediate and high) and two $\mathrm{N}$ conditions (low and high). We compared the responses in biomass production of the studied species and how these changes relative to the biomass of the competitor to address how invasion of the three alien species into a stand of the native grassland species is affected by (1) changes in water availability, (2) $\mathrm{N}$ addition and (3) the interaction between water availability and $\mathrm{N}$ addition. 


\section{Materials and methods}

\section{Study location and species}

To test interactions between the effects of water availability and $\mathrm{N}$ enrichment on alien plant invasion into a stand of a native grassland species, we did a mesocosm-pot experiment at the field station $\left(40^{\circ} 16^{\prime} \mathrm{N}, 115^{\circ} 36^{\prime} \mathrm{E}\right)$ in Huailai of China, which belongs to the State Key Laboratory of Earth Surface Processes and Resource Ecology, Beijing Normal University, China. During the 30 years (1971-2000), the mean annual temperature and precipitation of Huailai are $9.6{ }^{\circ} \mathrm{C}$ and $370 \mathrm{~mm}$, respectively (http://data.cma.cn). The average temperature and precipitation in the warmest month (August) are about $23.1{ }^{\circ} \mathrm{C}$ and $77.3 \mathrm{~mm}$, respectively (http://data.cma.cn). To create a stand of a temperate native grassland species, we chose the perennial grass species $A$. cristatum as a representative native species. It commonly occurs in Inner Mongolia grasslands, and is dominant in many places ( $\mathrm{Li}$ et al. 2016). To test whether the invasive alien species differ in their responses to water availability and $\mathrm{N}$ enrichment, we chose three invasive alien species as invaders based on the database of invasive alien species in China (http://www.chinaias.cn): $L$. perenne (Poaceae), L. virginicum (Brassicaceae) and $M$. sativa (Leguminosae). Both $L$. perenne and $M$. sativa are perennial herbs, and were introduced from Europe to China. L. virginicum is an annual herb, and was introduced from North America to China. All three invasive alien species occur frequently in Inner Mongolia grasslands. Seeds of $L$. perenne and L. virginicum were bulk sampled in four different natural populations, and within each populations, seeds were collected from at least ten individuals. Seeds of $M$. sativa and A. cristatum were acquired from Ulanqab Grassland Station (Inner Mongolia, China).

\section{Experimental set-up}

To compare the growth performance of invasive alien and native plants when growing in a stand of the native grassland species under different water and $\mathrm{N}$ conditions, we did a full factorial experiment. In this experiment, we grew each of the three invasive alien plant species (L. virginicum, L. perenne and $M$. sativa) in the center of a matrix of the native species (A. cristatum) under three different water availabilities (low, intermediate and high) and two $\mathrm{N}$ conditions (low and high). To compare whether the different water conditions and $\mathrm{N}$ conditions also affect the native species itself, we also grew the native species in the center of the same matrix of conspecific native species as a control. The experiment started on 13 July and ended on 6 September 2016.
We first filled $2 \mathrm{~L}$ pots with a 1:1 mixture of sand and vermiculite. To create a stand of the studied native grassland species, we sowed 15-20 seeds of A. cristatum in a circle around the center of each pot (diameter $=15 \mathrm{~cm})$. We also sowed 3-5 seeds of the native species or one of the three invasive alien plant species in the center of each pot to simulate plant invasions. After this, we randomly assigned the pots to positions in a common garden. We used a white plastic roof to intercept the rainfall when it was raining, and removed it when it was not raining. To ensure that the seeds would germinate well, we watered the soil to saturation every day at nightfall. Ten days after sowing, we applied the $\mathrm{N}$ treatment for the first time (see below for details). We checked the germination in each pot every day until there were no new seedlings germinating from the soil. On the 4th of August (i.e., 20 days after sowing), we thinned the seedlings to have one individual of the native or alien species in the center of the pot, and we thinned the native competitors to five individuals, so that they were positioned at equal distances in a circle around the central plant.

Twenty days after sowing, we applied the $\mathrm{N}$ treatment for the second time and started the water treatments. We applied the low and high soil $\mathrm{N}$ conditions using a modified Hoagland nutrient solution (see Online Resource 1). The two nutrient solutions differed in the concentration of $\mathrm{N}$, but contained the same concentrations of the other nutrients. To each pot, we supplied $100 \mathrm{~mL}$ of nutrient solution once every 10 days. For the low and high nutrient treatments, we used $\mathrm{N}$ concentrations of 2 and $6 \mathrm{mmol}$, respectively. For the water treatments, we supplied $200 \mathrm{ml}$ of water for the high treatment and $120 \mathrm{ml}$ of water for the intermediate treatment every 2-3 days. In the low treatment, we daily checked all pots and supplied $100 \mathrm{ml}$ of water to these pots if plants had started to wilt (i.e., lost leaf turgor). As the nutrients were supplied in liquid form, we did not apply the water treatments on the day when the nutrient solutions were supplied. We replicated each treatment combination five times, resulting in 120 pots ( 4 species 3 invasive species and 1 native species $] \times 3$ water treatments $\times 2 \mathrm{~N}$ treatments $\times 5$ replicates).

Eight weeks after the start of the water treatments, we separately harvested the aboveground biomass of the plant in the center of the pots (i.e., the target species) and the five individuals of $A$. cristatum around the center (i.e., the native competitor). As some of the central plants died during the experiment, we only harvested 110 pots at the end of the experiment. The harvest was finished in one day. All aboveground biomass was dried for at least $72 \mathrm{~h}$ at $80^{\circ} \mathrm{C}$, and then weighed. Based on the final aboveground biomass, we calculated the total biomass per pot (biomass of the target species + biomass of the five native competitor plants) and the biomass proportion of the target species (i.e., the biomass of the target species divided by the total biomass per pot). 


\section{Statistical analysis}

To test the effects of water availability and $\mathrm{N}$ enrichment on performance of the three alien and the one native target species in the stand of the native grassland species, we fitted linear models using the $\mathrm{lm}$ function in R 3.3.2 (R Core Team 2016). Aboveground biomass production of the target species, aboveground biomass production of the native competitor, total aboveground biomass per pot and aboveground biomass proportion of the target species (i.e., target biomass/total biomass) were the response variables. To meet the assumption of normality, biomass proportion of the target species, total biomass per pot and biomass production of the native competitor were square-root transformed, and the biomass production of the target species was naturallog transformed. We included water treatment (i.e., low, intermediate and high water availability), $\mathrm{N}$ treatment (i.e., low and high availability), target species identity and their two-way and three-way interactions as explanatory variables in the model. As we wanted to test the effects of the treatments on each alien target plant species versus the native target plant species, we coded the target species factor as three dummy variables $T_{\mathrm{Lp}}$ (i.e., L. perenne vs A. cristatum), $T_{\mathrm{Lv}}$ (i.e., $L$. virginicum vs $A$. cristatum) and $T_{\mathrm{Ms}}$ (i.e., $M$. sativa vs $A$. cristatum) to obtain the different contrasts of interest (Online Resource 2; Schielzeth 2010). In the linear model described above, we assessed the significance of all variables and their interactions with likelihood-ratio tests (Zuur et al. 2009; for details, see Online Resource 3) using the $1 \mathrm{r}$ test function in R 3.3.2 (R Core Team 2016). The outputs (including model estimates) of all linear models are presented in Online Resource 4.

\section{Results}

The invasive alien target species $L$. perenne and the native target species $A$. cristatum did not significantly differ in aboveground biomass (Table 1 and Fig. 1a), proportion biomass (Table 1 and Fig. 1d), and their effects on biomass of the competitor plants and total biomass per pot (Table 1; Figs. 1b, 1c). However, the two other invasive alien target species, L. virginicum and M. sativa, produced more biomass than the native target species A. cristatum (Table 1 and Fig. 1a). In addition, the total biomass per pot was also higher when the target species were either the invasive alien species L. virginicum or M. sativa rather than the native $A$. cristatum (Table 1 and Fig. 1c). This was not only because these two invasive alien target species produced more biomass than the native target species (Table 1 and Fig. 1a), but also partly because the alien target species $M$. sativa had a positive effect on the biomass of the native competitor plants (Table 1 and Fig. 1b). The biomass proportions of $L$.

Table 1 Results of linear models testing the effects of water availability (low, intermediate and high), nitrogen addition (low and high), tar-

tion and biomass proportion of target species, total biomass per pot and biomass production of the native competitor Agropyron cristatum

\begin{tabular}{|c|c|c|c|c|c|c|c|c|c|}
\hline \multirow[t]{2}{*}{ Parameters } & \multirow[b]{2}{*}{$d f$} & \multicolumn{2}{|c|}{$\begin{array}{l}\text { Biomass produc- } \\
\text { tion of target spe- } \\
\text { cies }(\ln )\end{array}$} & \multicolumn{2}{|c|}{$\begin{array}{l}\text { Biomass produc- } \\
\text { tion of native } \\
\text { competitor (sqrt) }\end{array}$} & \multicolumn{2}{|c|}{$\begin{array}{l}\text { Total biomass per } \\
\text { pot (sqrt) }\end{array}$} & \multicolumn{2}{|c|}{$\begin{array}{l}\text { Biomass proportion } \\
\text { of target species } \\
\text { (sqrt) }\end{array}$} \\
\hline & & $\chi^{2}$ & $P$ & $\chi^{2}$ & $P$ & $\chi^{2}$ & $P$ & $\chi^{2}$ & $P$ \\
\hline Nitrogen addition $(\mathrm{N})$ & 1 & 28.303 & $<0.0001$ & 3.9202 & 0.0477 & 15.312 & $<0.0001$ & 19.42 & $<0.0001$ \\
\hline Water availability $(\mathrm{W})$ & 2 & 65.197 & $<0.0001$ & 127.42 & $<0.0001$ & 125.97 & $<0.0001$ & 0.1038 & 0.9494 \\
\hline Lepidium virginicum vs Agropyron cristatum $\left(\mathrm{T}_{\mathrm{Lv}}\right)$ & 1 & 13.386 & 0.0002 & 0.049 & 0.8248 & 7.1516 & 0.0075 & 17.379 & $<0.0001$ \\
\hline Lolium perenne vs Agropyron cristatum $\left(T_{\mathrm{Lp}}\right)$ & 1 & 0.6831 & 0.4085 & 0.1501 & 0.6984 & 0.5593 & 0.4545 & 0.5667 & 0.4516 \\
\hline Medicago sativa vs Agropyron cristatum $\left(T_{\mathrm{Ms}}\right)$ & 1 & 14.707 & 0.0001 & 6.0879 & 0.0136 & 10.26 & 0.0014 & 7.3681 & 0.0066 \\
\hline $\mathrm{N}: \mathrm{W}$ & 2 & 2.0687 & 0.3554 & 8.6614 & 0.0132 & 4.8317 & 0.0893 & 6.4177 & 0.0404 \\
\hline $\mathrm{N}: T_{\mathrm{Lv}}$ & 1 & 12.298 & 0.0005 & 1.2367 & 0.2661 & 10.223 & 0.0014 & 10.373 & 0.0013 \\
\hline $\mathrm{N}: T_{\mathrm{Lp}}$ & 1 & 0.319 & 0.5722 & 1.143 & 0.2850 & 0.9219 & 0.3370 & 0.8968 & 0.3436 \\
\hline $\mathrm{N}: T_{\mathrm{Ms}}$ & 1 & 0.0019 & 0.9650 & 0.2442 & 0.6212 & 0.3638 & 0.5464 & 0.1095 & 0.7407 \\
\hline $\mathrm{W}: T_{\mathrm{Lv}}$ & 2 & 2.9453 & 0.2293 & 6.7752 & 0.0338 & 11.138 & 0.0038 & 0.8873 & 0.6417 \\
\hline $\mathrm{W}: T_{\mathrm{Lp}}$ & 2 & 6.7807 & 0.0337 & 2.0637 & 0.3563 & 4.2801 & 0.1177 & 4.6043 & 0.1000 \\
\hline $\mathrm{W}: T_{\mathrm{Ms}}$ & 2 & 4.3071 & 0.1161 & 3.7848 & 0.1507 & 5.2536 & 0.0723 & 5.3851 & 0.0677 \\
\hline $\mathrm{N}: \mathrm{W}: T_{\mathrm{Lv}}$ & 2 & 3.378 & 0.1847 & 2.8366 & 0.2421 & 3.7061 & 0.1568 & 7.423 & 0.0244 \\
\hline $\mathrm{N}: \mathrm{W}: T_{\mathrm{Lp}}$ & 2 & 3.2979 & 0.1922 & 0.2861 & 0.8667 & 0.9104 & 0.6343 & 3.375 & 0.1850 \\
\hline $\mathrm{N}: \mathrm{W}: T_{\mathrm{Ms}}$ & 2 & 0.9329 & 0.6272 & 1.4075 & 0.4947 & 1.4895 & 0.4748 & 0.4495 & 0.7987 \\
\hline
\end{tabular}

The effect of target species was included as three contrasts $\left(T_{\mathrm{Lv}}, T_{\mathrm{Lp}}, T_{\mathrm{Ms}}\right)$, each comparing one of the alien target species (Lepidium virginicum, Lolium perenne, Medicago sativa) to the native target species (A. cristatum) 

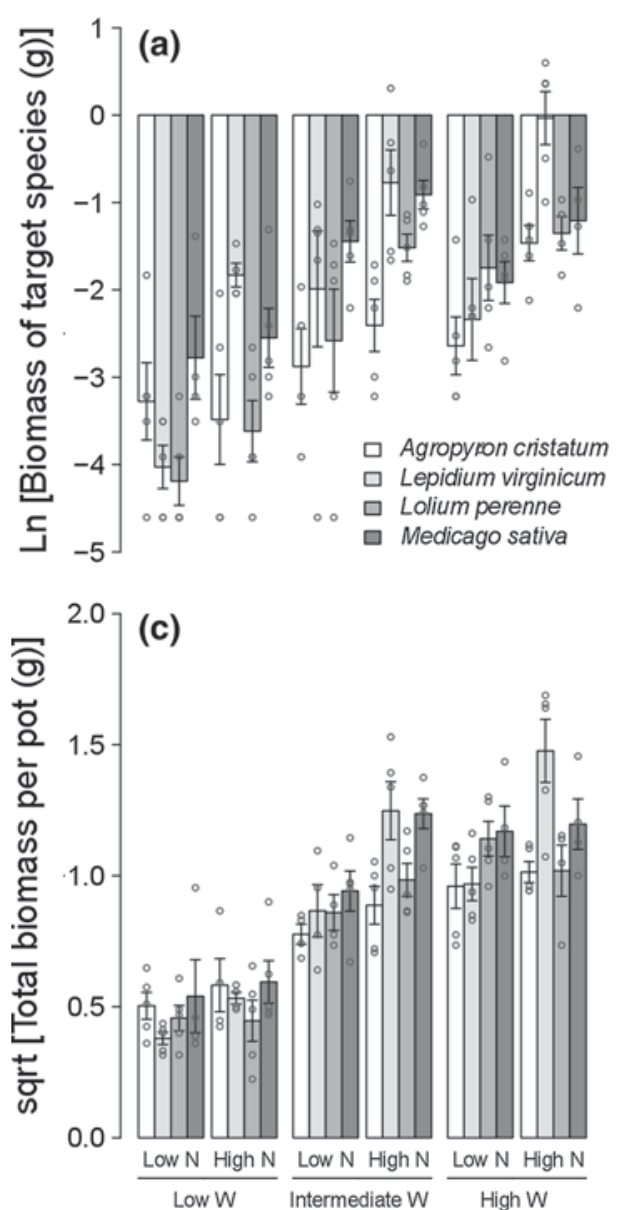

Fig. 1 a Mean values of biomass of invasive alien (Lepidium virginicum, Lolium perenne, Medicago sativa) and native (Agropyron cristatum) target species, $\mathbf{b}$ biomass proportion of target species, $\mathbf{c}$ total biomass per pot $\mathbf{d}$ and biomass of the native competitor A. cristatum

virginicum and $M$. sativa were nevertheless still higher than that of the native target species (Table 1 and Fig. 1d).

\section{Effects of water availability}

An increase in water availability significantly promoted biomass production of the three invasive alien and the one native target species (Table 1 and Fig. 1a). Compared to the native target species $A$. cristatum, the invasive alien species $L$. perenne increased its biomass more strongly in response to an increase in water availability, whereas the invasive alien species $L$. virginicum and $M$. sativa showed similar biomass increases (Table 1 and Fig. 1a). An increase in water availability also significantly enhanced the biomass production of the native competitors (Table 1 and Fig. 1b) and thus the total biomass production per pot (Table 1 and Fig. 1c). In pots with the invasive alien species L. virginicum, the increase in total biomass production was stronger than in the pots with the native target species A. cristatum
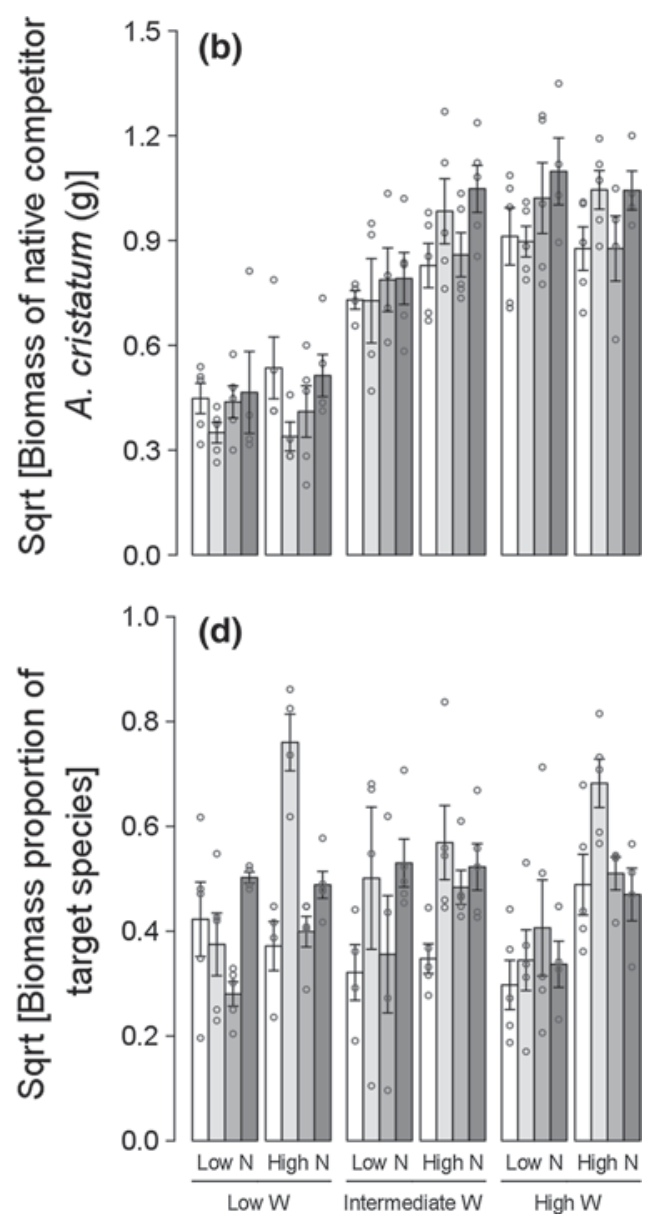

under different water (W) and $\mathrm{N}$ availabilities. Error bars represent SEs of the means. Individual points indicate the values for the replicates per species under each treatment combination. Data plotted in the figure are transformed

(Table 1 and Fig. 1c). Compared to the native target species A. cristatum, the invasive alien target species $L$. virginicum had a negative effect on biomass of the native competitors under low water availability, but a positive effect under intermediate and high water availability (Table 1 and Fig. 1b). The proportional biomass of the target species, however, was not affected by the watering treatments (Table 1 and Fig. 1d).

\section{Effects of $\mathbf{N}$ addition}

Nitrogen addition significantly increased the biomass production of the target species (Table 1 and Fig. 1a) and the native competitors (Table 1, Fig. $1 \mathrm{~b}$ ), and as a consequence the total biomass per pot (Table 1; Fig. 1c). As the target biomass increased more strongly than the competitor biomass, the proportion biomass of the target species was also increased by $\mathrm{N}$ addition (Table 1, Fig. 1d). Effects of $\mathrm{N}$ addition for pots with the invasive alien target species $L$. perenne and $M$. sativa were similar to those with the native 
target species A. cristatum (Table 1 and Fig. 1c). However, the positive effects of $\mathrm{N}$ addition on target plant biomass (Table 1 and Fig. 1a), biomass proportion of the target plant (Table 1 and Fig. 1d) and total biomass (Table 1 and Fig. 1c) were stronger when the target plant was $L$. virginicum than when it was the native A. cristatum.

\section{Interactive effects between water availability and N addition}

The biomass production of the native competitors increased more strongly in response to $\mathrm{N}$ addition when the water availability also increased (Table 1 and Fig. 1b). Although a similar trend is visible for biomass production of the target plants, it was not significant (Table 1 and Fig. 1a). Nevertheless, the biomass proportion of the target species increased significantly more in response to $\mathrm{N}$ addition when water availability also increased (Table 1 and Fig. 1d). The invasive alien species $L$. perenne and $M$. sativa showed similar responses of biomass proportion as the native A. cristata. However, the invasive alien species $L$. virginicum in contrast to native $A$. cristata showed the strongest response to nutrient addition under low water availability (Table 1 and Fig. 1d).

\section{Discussion}

Here we tested how water availability and changes in nutrient availability might affect performance of three invasive alien species into a stand of the native grass A. cristatum. Relative to the native species, two of the invasive alien species, L. virginicum and $M$. sativa, produced more biomass and accounted for a larger proportion of the total biomass per pot. Increasing water availability promoted biomass production both for the invasive alien and native target species in the center of each pot, as well as of the native competitors around the target plant. However, water availability did not change the competitive balance (i.e., biomass proportion) between the four target species and the native competitor. Averaged across the four target species and the three water availabilities, $\mathrm{N}$ addition also increased biomass production of the plants, but more so for the target plants than for the competitors, as the biomass proportion of the target species increased. Averaged across the three invasive alien and one native target species, the positive effect of $\mathrm{N}$ addition on the biomass proportion of the target species increased with increasing water availability. However, for the invasive alien species L. virginicum, the opposite was true. Therefore, future changes in water availability and $\mathrm{N}$ enrichment may affect the invasion success of the alien species differently.

Invasive alien plant species often show higher values than native plants for traits reflecting physiology, size and fitness (van Kleunen et al. 2010), and hence invasive plants often appear to be more competitive than native species (Kuebbing and Nunez 2016). However, not all invasive alien plant species can outcompete native species (Gioria and Osborne 2014). Our findings support the variable outcomes of competition between invasive and native species, as the invasive alien species L. virginicum and $M$. sativa had a higher performance and a higher competitive ability than the native species $A$. cristatum, whereas the invasive alien species $L$. perenne exhibited a competitive ability similar to the one of the native species.

Phylogenetically closely related species are likely to share ecological niches, and therefore, competition between conspecifics (i.e., intraspecific competition) and between closely related species should be stronger than competition between distantly related species (MacArthur and Levins 1967; Silvertown 2004; Violle et al. 2011). Possibly, because of this the proportional biomass of central target plants grown in competition with the native grass $A$. cristatum was lowest for the conspecific species (A. cristatum) and for the other grass species (L. perenne). However, the larger biomass proportions of the other two target species (L. virginicum and $M$. sativa) could also reflect their overall larger biomass production. Although our comparison between the native target species and the alien target species confounds intraspecific with interspecific competition, and included only one native species, the idea that invasive alien plant species are not necessarily always better competitors than native plant species has also been found in other studies (Seabloom et al. 2003; Dawson et al. 2012; Gioria and Osborne 2014; Liu and van Kleunen 2017).

Interestingly, we found that the native competitor produced more biomass when growing with the alien species $M$. sativa in the center than when growing with another plant of the native $A$. cristatum in the center. This could reflect that intraspecific competition is stronger than interspecific competition, but a similar effect was not found for the other two interspecific competitors. The results is surprising given that $M$. sativa, just like $L$. virginicum, produced more biomass than A. cristatum, and thus should have a stronger competitive effect. A possible explanation for the positive effect of $M$. sativa on A. cristatum could be the $\mathrm{N}$-fixation by the legume $M$. sativa. N-fixation of legumes can increase the availability of soil $\mathrm{N}$ from which also the neighboring competitors may benefit (Ouyang et al. 2016; Wu et al. 2017).

As low water availability is the major limiting factor for plant growth in arid and semiarid ecosystems (Noy-Meir 1973; Lauenroth 1979), aboveground net primary productivity of such ecosystems usually shows a close association with water availability (Bai et al. 2008; Wu et al. 2011; Sala et al. 2012). Not surprisingly, we thus found that all four plant species produced more biomass with increased water availability. It is thought that invasive alien species have a 
high phenotypic plasticity (Richards et al. 2006; Davidson et al. 2011), and because of this, invasive alien species are expected to grow better and thus outcompete native species with increasing resource availability (Richards et al. 2006). Our findings did not support this idea with regard to water availabiltiy, as we found that increased water availability did not affect the competitive balance (i.e., biomass proportions) of any of the species. This is actually in line with a recent meta-analysis showing that invasive alien and native plants respond similar to increased water availability (Liu et al. 2017). Therefore, although water availability is a key factor controlling biomass production, it alone is not necessarily an important factor determining the competitive balance of the three invasive alien species that we studied.

Nitrogen is another major limiting resource for aboveground net primary production of grassland ecosystems (LeBauer and Treseder 2008; Fay et al. 2015). Our findings corroborate this, as we showed that all four species produced more biomass with $\mathrm{N}$ addition. Successful alien plants often originate from anthropogenic habitats in their native range (Kalusova et al. 2017), and are thus likely to be adapted to high $\mathrm{N}$ levels (Dostal et al. 2013). Therefore, $\mathrm{N}$ addition might promote plant invasion (Davis et al. 2000; Bradley et al. 2010a). Indeed, many case studies found that $\mathrm{N}$ enrichment favored invasive plant species over native plants (Boulant et al. 2008; González et al. 2010; Seabloom et al. 2015). However, in our recent meta-analysis, we found that although invasive alien plants tended to benefit more from increased $\mathrm{N}$ than native plants, this difference was only marginally significant (Liu et al. 2017). Possibly, this variation reflects that invasive alien species respond more strongly to $\mathrm{N}$ addition when compared to rare native species but not when compared to common native species, such as A. cristatum (Dawson et al. 2012). In our study, only one of the three invasive alien species, L. virginicum, benefited more from $\mathrm{N}$ addition than the native species. This indicates that $\mathrm{N}$ addition can promote the invasiveness of some but not of all alien species.

The effects of soil $\mathrm{N}$ and water availability on ecosystem processes are generally interdependent (Harpole et al. 2007; Bai et al. 2008; Lu and Han 2010; Li et al. 2011). Therefore, interactions between $\mathrm{N}$ enrichment and water availability might also affect the performance of invasive alien plant species competing with natives. Although we found that water availability alone did not affect the competitive balance between the invasive alien species and the native species, the positive effect of $\mathrm{N}$ addition on the biomass proportion of the target species increased with increasing water availability. A notable exception, however, was the invasive alien species $L$. virginicum for which the positive effect of $\mathrm{N}$ addition was strongest under low water availability. The reason for this is not known and deserves further research. Although some studies showed that invasiveness of alien plants might decrease under drought conditions (Liu et al. 2017; Pearson et al. 2017), there are also studies showing that alien plant species were more resistant to drought than native plant species (Martinez-Vilalta and Piñol 2002; Boulant et al. 2008; Crous et al. 2012). Moreover, a recent experiment that increased temperatures in grassland plots, which also resulted in drought stress, showed that both naturalized and non-naturalized alien plants suffered less than native plants (Haeuser et al. 2017). Overall, the variable effects of drought on alien plant performance indicate the context specificity of plant invasions (Kueffer et al. 2013; van Kleunen et al. 2015b). However, another possible explanation for the previous mixed findings is that soil $\mathrm{N}$ availabilities varied among studies, and interacted with soil water availability to affect the competitive balance between invasive alien and native plant species of each specific study.

In addition to the effect of $\mathrm{N}$ addition on biomass proportion of the target species, we also found that the effects of $\mathrm{N}$ addition on biomass of the native competitors and on total biomass per pot were affected by water availability. The interactive effect between water availability and $\mathrm{N}$ addition on total biomass per pot was, however, only marginally significant. Nevertheless, other studies in the same grassland region, also indicate that $\mathrm{N}$ availability determines the productivity of grassland under non-limiting water availability, while water availability determines the productivity when it becomes more limiting than $\mathrm{N}$ availability. For example, Bai et al. (2010) manipulated several levels of $\mathrm{N}$ enrichment in two field sites in Inner Mongolia for four years, and found that $\mathrm{N}$ addition had no effect on the aboveground productivity of the community under dry conditions, whereas it could significantly improve the aboveground productivity of the community under relatively wet conditions in this region. This means that soil $\mathrm{N}$ availability would become another important limiting factor for the productivity of a community, with or without invasive alien species when water availability becomes less limited (Snyman 2002; Huxman et al. 2004).

\section{Conclusions}

Like many previous studies, we found strong evidence that soil-water availability and soil $\mathrm{N}$ are both major limiting factors for the productivity of temperate grasslands. As our study only simulated plant invasion of three invasive alien plant species into a stand of one native grassland species, and the experimental duration was relatively short, we cannot generalize from our results. More multi-species studies and long-term field studies are needed to test for more general patterns. Nevertheless, we found that performance of some invasive alien species in stands of native species can 
be affected by interactions between multiple global change components.

Acknowledgements We thank Huimin Li and Jingjing Song for their help in the field. This study was supported by National Natural Science Foundation of China (nos. 31470560 and 31540051). We thank Christa Gommel for English editing.

Author contribution statement YL conceived the experiments. YL and $\mathrm{XX}$ designed the experiments. ML performed the experiments and collected data. YL and MvK analyzed the data. YL wrote the first draft, with further inputs from ML, XX, ZZ, YT and MvK.

\section{Compliance with ethical standards}

Conflict of interest The authors declare that they have no conflict of interest.

\section{References}

Bai YF, Wu JG, Xing Q, Pan QM, Huang JH, Yang DL, Han XG (2008) Primary production and rain use efficiency across a precipitation gradient on the Mongolia plateau. Ecology 89:2140-2153. https://doi.org/10.1890/07-0992.1

Bai YF, Wu JG, Clark CM, Naeem S, Pan QM, Huang JH, Zhang LX, Han XG (2010) Tradeoffs and thresholds in the effects of nitrogen addition on biodiversity and ecosystem functioning: evidence from inner Mongolia Grasslands. Glob Change Biol 16:358-372. https://doi.org/10.1111/j.1365-2486.2009.01950.x

Bloor JMG, Pichon P, Falcimagne R, Leadley P, Soussana JF (2010) Effects of warming, summer drought, and $\mathrm{CO}_{2}$ enrichment on aboveground biomass production, flowering phenology, and community structure in an upland grassland ecosystem. Ecosystems 13:888-900. https://doi.org/10.1007/s10021-010-9363-0

Boulant N, Kunstler G, Rambal S, Lepart J (2008) Seed supply, drought, and grazing determine spatio-temporal patterns of recruitment for native and introduced invasive pines in grasslands. Divers Distrib 14:862-874. https://doi.org/10.111 1/j.1472-4642.2008.00494.x

Bradley BA, Blumenthal DM, Wilcove DS, Ziska LH (2010a) Predicting plant invasions in an era of global change. Trends Ecol Evol 25:310-318. https://doi.org/10.1016/j.tree.2009.12.003

Bradley BA, Wilcove DS, Oppenheimer M (2010b) Climate change increases risk of plant invasion in the Eastern United States. Biol Invas 12:1855-1872. https://doi.org/10.1007/s10530-009-9597-y

Bredenkamp GJ, Spada F, Kazmierczak E (2002) On the origin of northern and southern hemisphere grasslands. Plant Ecol 163:209-229. https://doi.org/10.1023/A:1020957807971

Crous CJ, Jacobs SM, Esler KJ (2012) Drought-tolerance of an invasive alien tree, Acacia mearnsii and two native competitors in fynbos riparian ecotones. Biol Invas 14:619-631. https://doi.org/10.1007/ s10530-011-0103-y

Davidson AM, Jennions M, Nicotra AB (2011) Do invasive species show higher phenotypic plasticity than native species and if so, is it adaptive? A meta-analysis. Ecol Lett 14:419-431. https://doi. org/10.1111/j.1461-0248.2011.01596.x

Davis MA, Grime JP, Thompson K (2000) Fluctuating resources in plant communities: a general theory of invasibility. J Ecol 88:528534. https://doi.org/10.1046/j.1365-2745.2000.00473.x

Dawson W, Fischer M, van Kleunen M (2012) Common and rare plant species respond differently to fertilisation and competition, whether they are alien or native. Ecol Lett 15:873-880. https:// doi.org/10.1111/j.1461-0248.2012.01811.x

Dostal P, Dawson W, van Kleunen M, Keser LH, Fischer M (2013) Central European plant species from more productive habitats are more invasive at a global scale. Glob Ecol Biogeogr 22:6472. https://doi.org/10.1111/j.1466-8238.2011.00754.x

Dukes JS, Chiariello NR, Cleland EE, Moore LA, Shaw MR, Thayer S, Tobeck T, Mooney HA, Field CB (2005) Responses of grassland production to single and multiple global environmental changes. PLoS Biol 3:e319. https://doi.org/10.1371/journ al.pbio.0030319

Fay PA, Prober SM, Harpole WS, Knops JM, Bakker JD, Borer ET, Lind EM, MacDougall AS, Seabloom EW, Wragg PD, Adler PB, Blumenthal DM, Buckley YM, Chu C, Cleland EE, Collins SL, Davies KF, Du G, Feng X, Firn J, Gruner DS, Hagenah N, Hautier Y, Heckman RW, Jin VL, Kirkman KP, Klein J, Ladwig LM, Li Q, McCulley RL, Melbourne BA, Mitchell CE, Moore JL, Morgan JW, Risch AC, Schutz M, Stevens CJ, Wedin DA, Yang LH (2015) Grassland productivity limited by multiple nutrients. Nat Plants 1:15080. https://doi.org/10.1038/nplants.2015.80

Funk JL, Vitousek PM (2007) Resource-use efficiency and plant invasion in low-resource systems. Nature 446:1079-1081. https://doi. org/10.1038/nature05719

Gioria M, Osborne BA (2014) Resource competition in plant invasions: emerging patterns and research needs. Front Plant Sci 5:501. https ://doi.org/10.3389/fpls.2014.00501

González AL, Kominoski JS, Danger M, Ishida S, Iwai N, Rubach A (2010) Can ecological stoichiometry help explain patterns of biological invasions? Oikos 119:779-790. https://doi.org/10.111 1/j.1600-0706.2009.18549.x

Haeuser E, Dawson W, van Kleunen M (2017) The effects of climate warming and disturbance on the colonization potential of ornamental alien plant species. J Ecol 105:1698-1708. https://doi. org/10.1111/1365-2745.12798

Harpole WS, Potts DL, Suding KN (2007) Ecosystem responses to water and nitrogen amendment in a California grassland. Glob Change Biol 13:2341-2348. https://doi.org/10.111 1/j.1365-2486.2007.01447.x

Holland EA, Braswell BH, Sulzman J, Lamarque JF (2005) Nitrogen deposition onto the United States and western Europe: synthesis of observations and models. Ecol Appl 15:38-57. https://doi. org/10.1890/03-5162

Huxman TE, Smith MD, Fay PA, Knapp AK, Shaw MR, Loik ME, Smith SD, Tissue DT, Zak JC, Weltzin JF, Pockman WT, Sala OE, Haddad BM, Harte J, Koch GW, Schwinning S, Small EE, Williams DG (2004) Convergence across biomes to a common rain-use efficiency. Nature 429:651-654. https://doi.org/10.1038/ nature 02561

IPCC (2013) Working group 1, fifth assessment report. Cambridge Univ. Press, Cambridge

Jia J, Dai Z, Li F, Liu Y (2016) How will global environmental changes affect the growth of alien plants? Front Plant Sci 7:1623. https:// doi.org/10.3389/fpls.2016.01623

Kalusova V, Chytry M, van Kleunen M, Mucina L, Dawson W, Essl F, Kreft H, Pergl J, Weigelt P, Winter M, Pysek P (2017) Naturalization of European plants on other continents: the role of donor habitats. Proc Natl Acad Sci USA. https://doi.org/10.1073/ pnas. 1705487114

Keller ED, Baisden WT, Timar L, Mullan B, Clark A (2014) Grassland production under global change scenarios for New Zealand pastoral agriculture. Geosci Model Dev 7:2359-2391. https://doi. org/10.5194/gmd-7-2359-2014

Keser LH, Dawson W, Song YB, Yu FH, Fischer M, Dong M, van Kleunen M (2014) Invasive clonal plant species have a greater root-foraging plasticity than non-invasive ones. Oecologia 174:1055-1064. https://doi.org/10.1007/s00442-013-2829-y 
Keser LH, Visser EJW, Dawson W, Song YB, Yu FH, Fischer M, Dong M, van Kleunen M (2015) Herbaceous plant species invading natural areas tend to have stronger adaptive root foraging than other naturalized species. Front Plant Sci 6. https://doi.org/10.3389/ fpls.2015.00273

Kuebbing SE, Nunez MA (2016) Invasive non-native plants have a greater effect on neighbouring natives than other non-natives. Nat Plants 2. https://doi.org/10.1038/nplants.2016.134

Kueffer C, Pysek P, Richardson DM (2013) Integrative invasion science: model systems, multi-site studies, focused meta-analysis and invasion syndromes. New Phytol 200:615-633. https://doi. org/10.1111/nph.12415

Lauenroth WK (1979) Grassland primary production: North American grasslands in perspective. In: French NR (ed) Perspectives in grassland ecology: Results and applications of the us/ibp grassland biome study. Springer, New York, pp 3-24

LeBauer DS, Treseder KK (2008) Nitrogen limitation of net primary productivity in terrestrial ecosystems is globally distributed. Ecology 89:371-379. https://doi.org/10.1890/06-2057.1

Lewis SL, Maslin MA (2015) Defining the anthropocene. Nature 519:171-180. https://doi.org/10.1038/nature14258

Li JZ, Lin S, Taube F, Pan QM, Dittert K (2011) Above and belowground net primary productivity of grassland influenced by supplemental water and nitrogen in Inner Mongolia. Plant Soil 340:253-264. https://doi.org/10.1007/s11104-010-0612-y

Li QY, Xu L, Pan XB, Zhang LZ, Li C, Yang N, Qi JG (2016) Modeling phenological responses of Inner Mongolia grassland species to regional climate change. Environ Res Lett 11:1-13. https://doi. org/10.1088/1748-9326/11/1/015002

Liu Y, van Kleunen M (2017) Responses of common and rare aliens and natives to nutrient availability and fluctuations. J Ecol 105:1111-1122. https://doi.org/10.1111/1365-2745.12733

Liu X, Zhang Y, Han W, Tang A, Shen J, Cui Z, Vitousek P, Erisman JW, Goulding K, Christie P, Fangmeier A, Zhang F (2013) Enhanced nitrogen deposition over China. Nature 494:459-462. https://doi.org/10.1038/nature11917

Liu Y, Oduor AMO, Zhang Z, Manea A, Tooth IM, Leishman MR, Xu X, van Kleunen M (2017) Do invasive alien plants benefit more from global environmental change than native plants? Glob Change Biol 23:3363-3370. https://doi.org/10.1111/gcb.13579

Lu XT, Han XG (2010) Nutrient resorption responses to water and nitrogen amendment in semi-arid grassland of Inner Mongolia, China. Plant Soil 327:481-491. https://doi.org/10.1007/s1110 4-009-0078-y

MacArthur R, Levins R (1967) The limiting similarity, convergence, and divergence of coexisting species. Am Nat 101:377-385

Martínez-Vilalta J, Piñol J (2002) Drought-induced mortality and hydraulic architecture in pine populations of the NE Iberian Peninsula. For Ecol Manag 161:247-256. https://doi.org/10.1016/ s0378-1127(01)00495-9

Naz BS, Kao SC, Ashfaq M, Rastogi D, Mei R, Bowling LC (2016) Regional hydrologic response to climate change in the conterminous United States using high-resolution hydroclimate simulations. Glob Planet Change 143:100-117. https://doi.org/10.1016/j. gloplacha.2016.06.003

Noy-Meir I (1973) Desert ecosystems: environment and producers. Annu Rev Ecol Evol Syst 4:25-51

Ouyang SN, Tian YQ, Liu QY, Zhang L, Sun Y, Xu XL, Liu YH (2016) Symbiotic nitrogen fixation and interspecific transfer by Caragana microphylla in a temperate grassland with N15 dilution technique. Appl Soil Ecol 108:221-227. https://doi.org/10.1016/j. apsoil.2016.08.011

Pearson DE, Ortega YK, Maron JL (2017) The tortoise and the hare: reducing resource availability shifts competitive balance between plant species. J Ecol 105:999-1009. https://doi. org/10.1111/1365-2745.12736
Phoenix GK, Hicks WK, Cinderby S, Kuylenstierna JCI, Stock WD, Dentener FJ, Giller KE, Austin AT, Lefroy RDB, Gimeno BS, Ashmore MR, Ineson P (2006) Atmospheric nitrogen deposition in world biodiversity hotspots: the need for a greater global perspective in assessing $\mathrm{N}$ deposition impacts. Glob Change Biol 12:470-476. https://doi.org/10.1111/j.1365-2486.2006.01104.x

Pyšek P, Pergl J, Essl F, Lenzner B, Dawson W, Kreft H, Weigelt P, Winter M, Kartesz J, Nishino M, Antonova LA, Barcelona JF, Cabezas FJ, Cardenas D, Cardenas-Toro J, Castano N, Chacon E, Chatelain C, Dullinger S, Ebel AL, Figueiredo E, Fuentes N, Genovesi P, Groom QJ, Henderson L, Inderjit Kupriyanov A, Masciadri S, Maurel N, Meerman J, Morozova O, Moser D, Nickrent D, Nowak PM, Pagad S, Patzelt A, Pelser PB, Seebens H, Shu WS, Thomas J, Velayos M, Weber E, Wieringa JJ, Baptiste MP, van Kleunen M (2017) Naturalized alien flora of the world: species diversity, taxonomic and phylogenetic patterns, geographic distribution and global hotspots of plant invasion. Preslia 89:203274. https://doi.org/10.23855/preslia.2017.203

Richards CL, Bossdorf O, Muth NZ, Gurevitch J, Pigliucci M (2006) Jack of all trades, master of some? On the role of phenotypic plasticity in plant invasions. Ecol Lett 9:981-993. https://doi.org /10.1111/j.1461-0248.2006.00950.x

Richardson DM, Pyšek P, Rejmánek M, Barbour MG, Panetta FD, West CJ (2000) Naturalization and invasion of alien plants: concepts and definitions. Divers Distrib 6:93-107. https://doi.org/10 .1046/j.1472-4642.2000.00083.x

Sala OE, Gherardi LA, Reichmann L, Jobbagy E, Peters D (2012) Legacies of precipitation fluctuations on primary production: theory and data synthesis. Philos Trans R Soc Lond B Biol Sci 367:3135-3144. https://doi.org/10.1098/rstb.2011.0347

Scherer-Lorenzen M, Elend A, Nöllert S, Schulze E-D (2000) Plant invasions in Germany: General aspects and impact of nitrogen deposition. In: Mooney HA, Hobbs RJ (eds) Invasive species in a changing world. Island Press, Washington, D.C., pp 351-368

Scherer-Lorenzen M, Venterink HO, Buschmann H (2007) Nitrogen enrichment and plant invasions: the importance of nitrogen-fixing plants and anthropogenic eutrophication. In: Nentwig W (ed) Biol Invasions. Springer, Berlin, pp 163-180

Schielzeth H (2010) Simple means to improve the interpretability of regression coefficients. Methods Ecol Evol 1:103-113. https://doi. org/10.1111/j.2041-210X.2010.00012.x

Seabloom EW, Harpole WS, Reichman OJ, Tilman D (2003) Invasion, competitive dominance, and resource use by exotic and native California grassland species. Proc Natl Acad Sci USA 100:1338413389. https://doi.org/10.1073/pnas. 1835728100

Seabloom EW, Borer ET, Buckley YM, Cleland EE, Davies KF, Firn J, Harpole WS, Hautier Y, Lind EM, MacDougall AS, Orrock JL, Prober SM, Adler PB, Anderson TM, Bakker JD, Biederman LA, Blumenthal DM, Brown CS, Brudvig LA, Cadotte M, Chu C, Cottingham KL, Crawley MJ, Damschen EI, Dantonio CM, DeCrappeo NM, Du G, Fay PA, Frater P, Gruner DS, Hagenah N, Hector A, Hillebrand H, Hofmockel KS, Humphries HC, Jin VL, Kay A, Kirkman KP, Klein JA, Knops JM, La Pierre KJ, Ladwig L, Lambrinos JG, Li Q, Li W, Marushia R, McCulley RL, Melbourne BA, Mitchell CE, Moore JL, Morgan J, Mortensen B, O'Halloran LR, Pyke DA, Risch AC, Sankaran M, Schuetz M, Simonsen A, Smith MD, Stevens CJ, Sullivan L, Wolkovich E, Wragg PD, Wright J, Yang L (2015) Plant species' origin predicts dominance and response to nutrient enrichment and herbivores in global grasslands. Nat Commun 6:7710. https://doi.org/10.1038/ ncomms 8710

Seebens H, Essl F, Dawson W, Fuentes N, Moser D, Pergl J, Pysek P, van Kleunen M, Weber E, Winter M, Blasius B (2015) Global trade will accelerate plant invasions in emerging economies under climate change. Glob Change Biol 21:4128-4140. https://doi. org/10.1111/gcb.13021 
Seebens H, Blackburn TM, Dyer EE, Genovesi P, Hulme PE, Jeschke JM, Pagad S, Pysek P, Winter M, Arianoutsou M, Bacher S, Blasius B, Brundu G, Capinha C, Celesti-Grapow L, Dawson W, Dullinger S, Fuentes N, Jager H, Kartesz J, Kenis M, Kreft H, Kuhn I, Lenzner B, Liebhold A, Mosena A, Moser D, Nishino M, Pearman D, Pergl J, Rabitsch W, Rojas-Sandoval J, Roques A, Rorke S, Rossinelli S, Roy HE, Scalera R, Schindler S, Stajerova K, Tokarska-Guzik B, van Kleunen M, Walker K, Weigelt P, Yamanaka T, Essl F (2017) No saturation in the accumulation of alien species worldwide. Nat Commun 8:14435. https://doi. org/10.1038/ncomms 14435

Shaw MR, Zavaleta ES, Chiariello NR, Cleland EE, Mooney HA, Field CB (2002) Grassland responses to global environmental changes suppressed by elevated $\mathrm{CO}_{2}$. Science 298:1987-1990. https://doi. org/10.1126/science. 1075312

Silvertown J (2004) Plant coexistence and the niche. Trends Ecol Evol 19:605-611. https://doi.org/10.1016/j.tree.2004.09.003

Snyman HA (2002) Short-term response of rangeland botanical composition and productivity to fertilization $(\mathrm{N}$ and $\mathrm{P})$ in a semi-arid climate of South Africa. J Arid Environ 50:167-183. https://doi. org/10.1006/jare.2001.0858

R Core Team (2016) R: a language and environment for statistical computing. R Foundation for Statistical Computing, Vienna. https ://www.R-project.org/

van Kleunen M, Weber E, Fischer M (2010) A meta-analysis of trait differences between invasive and non-invasive plant species. Ecol Lett 13:235-245. https://doi.org/10.1111/j.1461-0248.2009.01418 .x

van Kleunen M, Dawson W, Essl F, Pergl J, Winter M, Weber E, Kreft H, Weigelt P, Kartesz J, Nishino M, Antonova LA, Barcelona JF, Cabezas FJ, Cardenas D, Cardenas-Toro J, Castano N, Chacon E, Chatelain C, Ebel AL, Figueiredo E, Fuentes N, Groom QJ, Henderson L, Inderjit Kupriyanov A, Masciadri S, Meerman J,
Morozova O, Moser D, Nickrent DL, Patzelt A, Pelser PB, Baptiste MP, Poopath M, Schulze M, Seebens H, Shu WS, Thomas J, Velayos M, Wieringa JJ, Pysek P (2015a) Global exchange and accumulation of non-native plants. Nature 525:100-103. https:// doi.org/10.1038/nature14910

van Kleunen M, Dawson W, Maurel N (2015b) Characteristics of successful alien plants. Mol Ecol 24:1954-1968. https://doi. org/10.1111/mec.13013

Vilà M, Espinar JL, Hejda M, Hulme PE, Jarosik V, Maron JL, Pergl J, Schaffner U, Sun Y, Pysek P (2011) Ecological impacts of invasive alien plants: a meta-analysis of their effects on species, communities and ecosystems. Ecol Lett 14:702-708. https://doi.org/ 10.1111/j.1461-0248.2011.01628.x

Violle C, Nemergut DR, Pu Z, Jiang L (2011) Phylogenetic limiting similarity and competitive exclusion. Ecol Lett 14:782-787. https ://doi.org/10.1111/j.1461-0248.2011.01644.x

Vitousek PM, DAntonio CM, Loope LL, Westbrooks R (1996) Biological invasions as global environmental change. Am Sci 84:468-478

Wu ZT, Dijkstra P, Koch GW, Penuelas J, Hungate BA (2011) Responses of terrestrial ecosystems to temperature and precipitation change: a meta-analysis of experimental manipulation. Glob Change Biol 17:927-942. https://doi.org/10.111 1/j.1365-2486.2010.02302.x

Wu G-L, Liu Y, Tian F-P, Shi Z-H (2017) Legumes functional group promotes soil organic carbon and nitrogen storage by increasing plant diversity. Land Degrad Dev 28:1336-1344. https://doi. org/10.1002/ldr.2570

Zavaleta ES, Shaw MR, Chiariello NR, Mooney HA, Field CB (2003) Additive effects of simulated climate changes, elevated $\mathrm{CO}_{2}$, and nitrogen deposition on grassland diversity. Proc Natl Acad Sci USA 100:7650-7654. https://doi.org/10.1073/pnas.0932734100

Zuur A, Ieno E, Walker N, Saveliev A, Smith G (2009) Mixed effects models and extensions in ecology with R. Springer, New York 